\title{
Phytophagous mites (Acari: Eriophyoidea) recorded from Svalbard, including the description of a new species
}

\author{
Agnieszka Kiedrowicz ${ }^{1}$ Brian G. Rector ${ }^{2} \cdot$ Krzysztof Zawierucha $^{1} \cdot$ \\ Wiktoria Szydło $^{1}$ Anna Skoracka ${ }^{1}$
}

Received: 4 May 2015/Revised: 20 November 2015/Accepted: 3 December 2015/Published online: 4 January 2016

(C) The Author(s) 2016. This article is published with open access at Springerlink.com

\begin{abstract}
Eriophyoid mites (Eriophyoidea) are minute phytophagous mites with great economic importance and great invasive potential. In spite of their demonstrated impact on ecosystem functions, knowledge of eriophyoid mite fauna in the Arctic is lacking. To date, only eight eriophyoid mite species have been recorded from the entire region north of the Arctic Circle. The Svalbard archipelago is one of the most biologically investigated Arctic areas. Despite the fact that studies on invertebrates on Svalbard have been conducted for more than one hundred years, eriophyoids have never been recorded before from this place, except for one likely accidental record of a single specimen belonging to the genus Eriophyes. Thus, each new study of eriophyoid mite fauna in this region is important. In this paper, a new species of eriophyoid mite, Cecidophyes siedleckii $\mathrm{n}$. sp., is described and illustrated. Nucleotide sequence data (D2 region of 28S rDNA) were employed to complement traditional morphological taxonomy. The first record of Aceria saxifragae (Rostrup 1900) from Svalbard is also provided, with supplementary morphological descriptions and illustrations. Eriophyoid mites represent an important and underutilized taxon that is available to ecologists studying the effects of changing climatic conditions on Svalbard.
\end{abstract}

\section{Agnieszka Kiedrowicz}

kiedra@amu.edu.pl

1 Department of Animal Taxonomy and Ecology, Institute of Environmental Biology, Adam Mickiewicz University, Umultowska 89, 60-687 Poznań, Poland

2 USDA-ARS, Great Basin Rangelands Research Unit, 920 Valley Road, Reno, NV 89512, USA
Keywords Arctic biology - Eriophyidae - Extreme environments · Molecular taxonomy · Herbivorous mites . DNA barcoding

\section{Introduction}

In polar regions, invertebrates occupy virtually all ecological niches, from the deep ocean floor to the surfaces of glaciers, including extreme environments, such as nunataks, tundra, and polar deserts, and they often constitute significant components of these harsh ecosystems (e.g., Dastych 1985; Janiec 1996; Dastych and Drummond 1996; Porazińska et al. 2004; Coulson et al. 2014b; Górska et al. 2014; Zawierucha et al. 2015). The past two decades have seen a rapid increase in research interest toward invertebrates in the Svalbard archipelago (e.g., Lippert et al. 2001; Coulson et al. 2003, 2014a; Johnsen et al. 2014; Pilskog et al. 2014; Zawierucha et al. 2015). Currently, the terrestrial invertebrate fauna of Svalbard consists of over 1000 species (Coulson et al. 2014b), and invertebrates are still being discovered in this region as both new records and new species to science (e.g., Kaczmarek et al. 2012; Zawierucha 2013; Zawierucha et al. 2013; Dabert et al. 2014; Coulson et al. 2014a, b; Coulson et al. 2015). However, while the invertebrate fauna of Svalbard is among the best known for any Arctic region (Hodkinson 2013), only about 115 mite (Acari) species have been recorded so far from the Svalbard archipelago, with the majority of them being soil-inhabiting Mesostigmata and Oribatida (Coulson et al. 2014b). Mites occupy almost every habitat on Earth and are an important component of every environment. Many mite species have evolved in associations with other organisms (i.e., plant or animal hosts) that function as their 
permanent or temporary habitats (Walter and Proctor 2013). Studies of parasitic or phytophagous organisms can provide insights into ecosystem functions. On Svalbard, for example, a thorough understanding of the biotic constraints to the proliferation and spread of plant species, particularly non-native species, is important when considering their ability to compete for available habitat with other plant species.

Previous studies on the parasitic invertebrates in the Svalbard archipelago have focused mostly on Nematoda, Cestoda, Acanthocephala, and Insecta (e.g., Hackman and Nyholm 1968; Halvorsen and Bye 1999; Kuklin et al. 2004; Stien et al. 2010), while a few studies have focused on parasitic Acari associated with birds (Gwiazdowicz et al. 2012; Dabert et al. 2014) and polyphagous Bryobia species (Coulson and Refseth 2004). Among phytophagous mites, only two species, both Tetranychidae (viz., Bryobia borealis Oudemans, 1930, and Bryobia praetiosa Koch, 1836), have been recorded from Svalbard (Summerhayes and Elton 1928; Thor 1930, 1934; MacFadyen 1954; Coulson and Refseth 2004), notwithstanding the well-described flora of the Svalbard archipelago, which includes 173 recorded vascular plant species, as well as 373 moss and 597 lichen species (Jónsdóttir 2005). Only one plantfeeding mite in the family Eriophyidae has ever been recorded from Svalbard, a possibly accidental record of a single specimen belonging to the genus Eriophyes (Thor 1934). In that case, neither the mite species nor its host plant were identified.

The eriophyoid mites are among the most economically important groups of phytophagous Acari (Lindquist and Amrine 1996). They cause direct damage to their host plants and often transmit plant viruses (Duso et al. 2010). Moreover, they have great invasive potential (Navia et al. 2010) due to their ability to spread undetected via windborne or human-mediated dispersal (Michalska et al. 2010). Given that the Arctic tundra is influenced by climate change (e.g., Walkera et al. 2006; Coulson 2013), greater knowledge of new phytophagous organisms and potential vectors of plant disease in this region is urgently needed.

Eriophyoid mite identification is often hampered by their minute size and structural simplicity (Lindquist and Amrine 1996), as well as the occurrence of cryptic lineages (Skoracka et al. 2012, 2013, 2014; Miller et al. 2013). In this paper, we describe a new species of eriophyoid plantfeeding mite, Cecidophyes siedleckii n. sp., using DNA data (D2 region of $28 \mathrm{~S}$ rDNA) to complement traditional morphological taxonomy. In addition, we provide the first record of Aceria saxifragae (Rostrup, 1900) from Svalbard with supplementary morphological data to augment the original description.

\section{Materials and methods}

A sample of Saxifraga oppositifolia L. 1753 was collected in August 2011 from the northern coast of Hornsund, Wedel Jarlsberg Land, near the Stanisław Siedlecki Polish Polar Station "Hornsund" (Fig. 1). The plant was allowed to dry slowly, and dried plant parts were examined in the laboratory under a stereomicroscope (Olympus SZ40) to check for the presence of eriophyoid mites or deformations of plant tissues typical of some eriophyoid mite infestations (e.g., galls and enlarged buds). The dried plant parts were then soaked in water for several hours and then re-examined under a stereomicroscope. No plant deformations were noted. During examination, all parts of plants were destroyed to search for mites, including inside flowers and buds. Several eriophyoid mite specimens were found in this way; these were collected and mounted on microscope slides in Heinze and Hoyer media according to a standard protocol (de Lillo et al. 2010), and then studied taxonomically using a phase-contrast microscope (Olympus BX41).

Morphological nomenclature follows Lindquist (1996), data measurements follow de Lillo et al. (2010), and systematic classification follows Rostrup (1900), Liro (1940) and Amrine et al. (2003). Measurements refer to the lengths of a given structure in micrometers unless otherwise stated. In the description of the new species, the holotype female measurement precedes the corresponding range for paratypes (given in parentheses). Micrographs were made using an Olympus BX41 microscope and Olympus Camedia C-5050 camera.

Several of the collected eriophyoid mite specimens were rinsed in $98 \%$ alcohol and stored in $180 \mu \mathrm{l}$ of ATL buffer for several days. A nondestructive method of DNA extraction was applied, as described by Dabert et al. (2008), using the DNeasy Blood \& Tissue Kit (Qiagen, Hilden, Germany). Post-extraction, specimen cuticles were transferred to $70 \%$ ethanol and mounted on slides for identification. A fragment of the D2 region of $28 \mathrm{~S}$ ribosomal DNA (28S rDNA) was amplified using the primers D1D2fw2 (Sonnenberg et al. 2007) and 28SR0990 (Mironov et al. 2012). PCR was conducted in a $10 \mu$ reaction volume containing $5 \mu \mathrm{l}$ of Type-it Multiplex PCR Master Mix (Qiagen, Hilden, Germany), $50 \mathrm{pM}$ of each primer, and $4 \mu \mathrm{l}$ of DNA template.

The thermal cycling profile consisted of an initial denaturation step of $5 \mathrm{~min}$ at $95{ }^{\circ} \mathrm{C}$, followed by 35 cycles of 30-s denaturation at $95{ }^{\circ} \mathrm{C}, 30$-s annealing at $50{ }^{\circ} \mathrm{C}$, and 1 -min extension at $72{ }^{\circ} \mathrm{C}$, with a final step of $15 \mathrm{~min}$ at $72{ }^{\circ} \mathrm{C}$. The reaction products were diluted by half, and $5 \mu \mathrm{l}$ of each diluted PCR product was stained with the GelRed Nucleic Acid Gel Stain (Biotium, Hayward, CA, USA) and checked by electrophoresis on a $1 \%$ agarose gel. The 


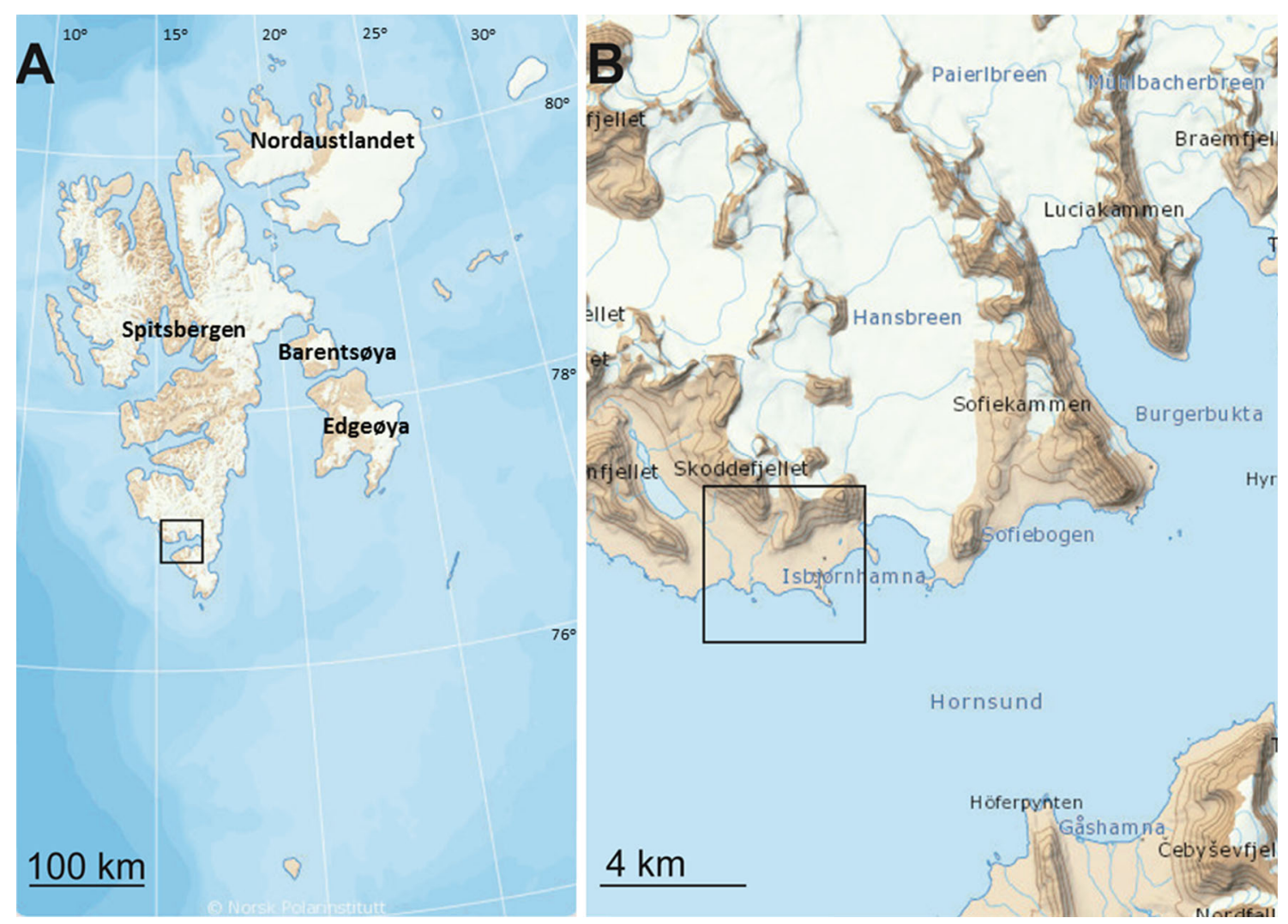

Fig. 1 Studied area: a Svalbard Archipelago, scale bar $100 \mathrm{~km}$; b Study area, scale bar $4 \mathrm{~km}$

samples were sequenced with the following primers to obtain the D2 region of the $28 \mathrm{~S}$ rDNA: universal forward primer D1D2fw2, specific forward primer Er28SF05, and specific reverse primer Er28SR05 (Szydło et al. 2015). Sequencing was performed using BigDye Terminator version 3.1 on an ABI Prism 3130XL Genetic Analyzer (Applied Biosystems, Foster City, CA, USA). The forward and reverse sequences were aligned and assembled with BioEdit version 7 software (Hall 1999). Trace files were aligned and edited with MEGA6 (Tamura et al. 2013). Four obtained sequences of $627 \mathrm{bp}$ were deposited in NCBI (National Center for Biotechnology Information) GenBank database under Accession Numbers KR072631, KR072632, KR072633, and KR072634.

The taxonomic identification of specimen cuticles showed that DNA sequences were obtained from only one of the two collected species, belonging to the genus $\mathrm{Ce}$ cidophyes Nalepa, 1887. Identification of the study subject to the genus Cecidophyes was confirmed by the Basic Local Alignment Search Tool (Standard Nucleotide BLAST; NCBI), optimized for blastn (somewhat similar sequences) and megablast (highly similar sequences). Two sequences of Cecidophyes spp. from the NCBI GenBank database (Accession Numbers: KF782480 and KF782481) were aligned with the Cecidophyes n. sp. sequences to calculate the Kimura-2-parameter (K2P) distances between sequences with MEGA6 software.

\section{Results}

Two different eriophyoid species were identified from the samples of $S$. oppositifolia based on morphological study: A. saxifragae (Rostrup, 1900) and C. siedleckii n. sp. The description of $C$. siedleckii n. sp. is provided below with DNA data, and the description of $A$. saxifragae is supplemented.

Family Eriophyidae Nalepa, 1898

Subfamily Cecidophyinae Keifer, 1966

Tribe Cecidophyini Keifer, 1966

Genus Cecidophyes Nalepa, 1887

C. siedleckii n. sp. Kiedrowicz, Szydło \& Skoracka

(Figs. 2, 3)

Female (holotype and seven paratypes): body spindleform, 195 (163-203); width 67 (63-70). Gnathosoma 20 (25-30), projecting forward and down, dorsal pedipalpal genual setae $d 5$ (4-7), setae ep 4 (3-4), chelicerae 25 (22-25). Prodorsal shield 38 (41-42), 50 (48-49) wide, subrectangular, anterior lobe 12 (11-13) long, 21 (20-22) wide. 
Fig. 2 Cecidophyes siedleckii n. sp. female: a ventral view; b coxogenital region; c anterodorsal mite; scale bar $10 \mu \mathrm{m}$
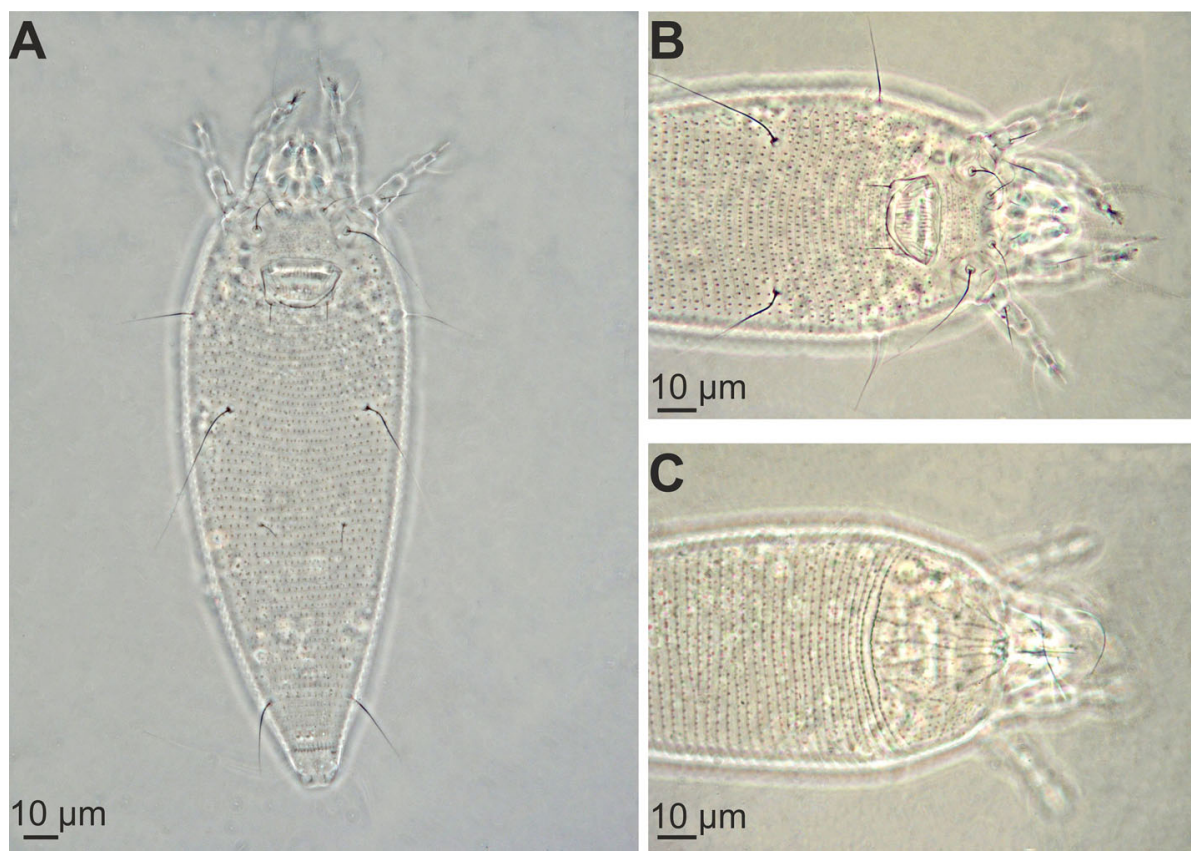

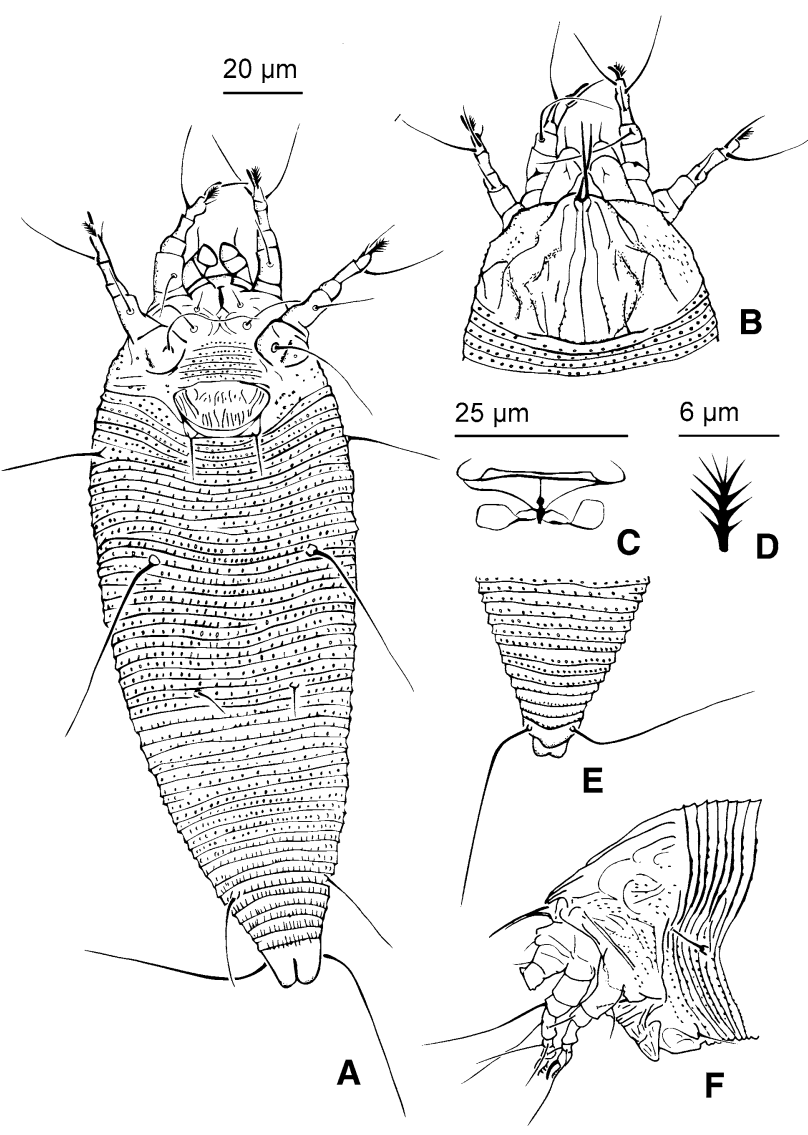

Fig. 3 Cecidophyes siedleckii $\mathrm{n}$. sp. female: a ventral mite; $\mathbf{b}$ anterodorsal mite; c internal genitalia; d empodium; e posterodorsal mite; f anterolateral mite; scale bar $\mathbf{a}, \mathbf{b}, \mathbf{e}, \mathbf{f}-20 \mu \mathrm{m} ; \mathbf{c}-25 \mu \mathrm{m} ; \mathbf{d}-$ $6 \mu \mathrm{m}$
Shield pattern with complete median line and admedian lines; submedian lines incomplete and appear as six short lines. Lack of scapular setae sc. Legs with all usual segments and setae present. Leg I 32 (27-34); femur 10 (8-11), seta bv 14 (10-15); genu 5 (4-5), seta l” 32 (30-34); tibia 8 (8-9), seta l' 8 (7-10); tarsus 7 (6-8), setae: $f t$ ' 20 (18-25), ft' 18 (14-22), u' 4 (3-5); solenidion $\omega 6$ (5-7); empodium simple 5 (4-6) with 5 (4-5) rays. Leg II 29 (27-31); femur 11 (9-11), seta $b v 12$ (10-13); genu 5 (4-5), seta $l$ " 6 (6-8); tibia 7 (6-7); tarsus 7 (6-7), setae: $f t$ ” 21 (20-26), ft' 5 (5-8), u' 4 (3-4); solenidion $\omega 6$ (6-8); empodium simple 4 (4-6) with 5 (4-5) rays. Coxae smooth. Setae $1 b 4$ (4-5), tubercles $1 b 11$ (8-11) apart; setae 1a 17 (12-18), tubercles 1a 14 (13-14) apart; setae $2 a$ 36 (32-35), tubercles $2 a 27$ (23-28) apart; distance between tubercles $1 b$ and $1 a 5$ (5-6), distance between tubercles $1 a$ and $2 a 9$ (7-10). Genital opening 15 (15-17), 28 (26-28) wide, genital coverflap with 24 (22-30) longitudinal ridges in two rows; setae $3 a 10$ (7-11), tubercles $3 a 19$ (18-19) apart. Opisthosoma spindleform; 50 (48-52) dorsal annuli, 53 (52-57) ventral annuli with minute, oval microtubercles situated near rear margin of the annuli. Opisthosomal setae: c2 34 (25-29), tubercles 58 (58-67) apart, on 8th (6-8) ventral annulus; $d 50$ (45-51), tubercles 43 (43-44) apart, on 17th (16-18) ventral annulus; e 7 (7-9), tubercles 25 (25-26) apart, on 29th (27-31) ventral annulus; $f 22$ (21-26), tubercles 25 (25-26) apart, on 48th (46-51) ventral annulus, 5th (5-7) annulus from rear. Setae $h 1$ absent; setae $h 248$ (48-68), 10 (10) apart. 
Type material: Holotype female [SVERCEC01], paratypes females-seven females [SVERCEC02, SVERCEC03, SVERCEC04, SVERCEC05, SVERCEC06, SVERCEC07, SVERCEC08] from northern coast of Hornsund, Wedel Jarlsberg Land, $77^{\circ} 00^{\prime} \mathrm{N}, 15^{\circ} 19.8^{\prime}$, August 2011 from S. oppositifolia (Saxifragaceae), leg. $\mathrm{K}$. Zawierucha. Material is deposited in the collection of the Faculty of Biology, Adam Mickiewicz UniversityAMU, Poznań, Poland, and in the collection of Department of Applied Entomology, Faculty of Horticulture, Biotechnology and Landscape Architecture, Warsaw University of Life Sciences-SGGW, Warsaw, Poland.

Relation to the host: Free-living on upper part of leaves. Mites were not found inside flowers or buds. No plant deformations were noted.

Etymology: The specific name is the noun in genitive case derived from the surname of the founder of the Polish Polar Station on Svalbard, where these specimens were collected.

DNA data: A 627-bp fragment of the D2 region of $28 \mathrm{~S}$ rDNA was amplified and sequenced from four female specimens of $C$. siedleckii n. sp. (GenBank Acc. KR072631, KR072632, KR072633, KR072634). This DNA marker has been utilized successfully in phylogenetic studies at the species level and has been proposed as a DNA bar code for taxonomic differentiation of animal species (Sonnenberg et al. 2007). This DNA fragment has also been successfully applied to the delimitation of species (including cryptic species) in eriophyoid mites (e.g., Skoracka et al. 2013, 2014; Lewandowski et al. 2014). No variability between obtained sequences was detected. Interspecific K2P divergence between new species and two other Cecidophyes spp., namely Cecidophyes hirsutes Xue, Song and Hong, 2011 and Cecidophyes truncatis Xue, Song and Hong, 2011, was 12.3 and $18.1 \%$, respectively, which corresponded to divergences between congeneric eriophyoid species reported in other studies (e.g., Lewandowski et al. 2014).

Differential diagnosis: Cecidophyes siedleckii is the first Cecidophes species found on plants belonging to the family Saxifragaceae. Cecidophyes glaber (Nalepa, 1892) has been described from Sedum reflexum L., Crassulaceae, which together with Saxifragaceae belongs to the same order, Saxifragales. The new species is similar to $C$. glaber in having complete median and admedian lines on the prodorsal shield; however, these lines are composed of short dashes in C. glaber, whereas they are continuous in C. siedleckii. Additionally, these two species can be differentiated by the shapes of the submedian lines and dorsal microtubercles. Cecidophyes glaber has regular and complete submedian lines and large dorsal microtubercles.
Cecidophyes siedleckii has irregular and interrupted submedian lines and minute dorsal tubercles. The new species can be also differentiated from Cecidophes galii (Karpelles, 1884) described from Galium aparine L. (Rubiaceae) by the shapes of submedian lines (which are complete and regular in C. galii and irregular and interrupted in $C$. siedleckii) and the number of opisthosomal annuli (near 70 in $C$. galii and fewer than 60 in C. siedleckii). The prodorsal shield design, composed of longitudinal lines, and the knotless tarsal solenidion in the new species differentiate it from Cecidophyes truncatis (Xue, Hong and Song, 2001) and Cecidophyes hirsutes (Xue, Hong and Song, 2001), which both have network shield designs and knobbed tarsal solenidions. Cecidophyes hirsutes also differs from the new species by having elliptical microtubercles (compared to minute microtubercles in $C$. siedleckii). Many North American Cecidophyes species have network shield designs, which differentiate them from the new species (Baker et al. 1996). One example is $\mathrm{Ce}$ cidophyes tampae Keifer, 1966, which differs from the new species in having elongate dorsal microtubercles, a genital coverflap with 16 ridges, coxae with curved lines, and a 6-rayed empodium. By contrast, $C$. siedleckii has minute microtubercles, a genital coverflap with 22-30 ridges, smooth coxae, and a 4- to 5-rayed empodium.

Family Eriophyidae Nalepa, 1898

Subfamily Eriophyinae Nalepa, 1898

Tribe Aceriini Amrine and Stasny, 1994

Genus Aceria Keifer, 1944

A. saxifragae (Rostrup, 1900)

(Figs. 4, 5)

Female (six specimens): body vermiform 186-268; 63-80 wide. Gnathosoma 29-32, projecting forward and down, dorsal pedipalpal genual setae $d 5-7$, setae ep 4 , chelicerae 22-26. Prodorsal shield 32-40, 42-45 wide, subrectangular, without anterior lobe. Shield pattern: incomplete median line, which appears as a long line in the front $3 / 4$ with a transverse line in the rear $1 / 3$ and two short arcs at the rear shield margin; admedian lines complete; submedian lines form a mosaic pattern. Scapular setae sc 19-24, tubercles sc 25-30 apart. Legs with all usual segments and setae present. Leg I 30-35; femur 9-10, seta $b v 7-8$; genu 5-6, seta l" 25-30; tibia 7-8, seta l' 7-8; tarsus 8, setae: $f t$ " 22-26, ft' 12-17, $u$ ' 3-6; solenidion $\omega$ 8-9; empodium simple 6-7 with 5 rays. Leg II 26-31; femur 8-10, seta $b v$ 8-12; genu 4-6, seta $l$ " 10-11; tibia 4-6; tarsus 6-7, setae: $f t$ " 21-27, ft' 6-9, u' 5-6; solenidion $\omega$ 8-9; empodium simple 6-8 with five rays. Coxae with spots. Setae $1 b 6-8$, tubercles $1 b$ 14-15 apart; setae $1 a$ 20-22, tubercles $1 a$ 11-12 apart; setae $2 a$ 20-35, tubercles $2 a 27$ apart; distance between tubercles $1 b$ and $1 a$ 7-9, distance 
Fig. 4 Aceria saxifragae female: a ventral view; b anterodorsal mite; c coxogenital region; scale bar $10 \mu \mathrm{m}$
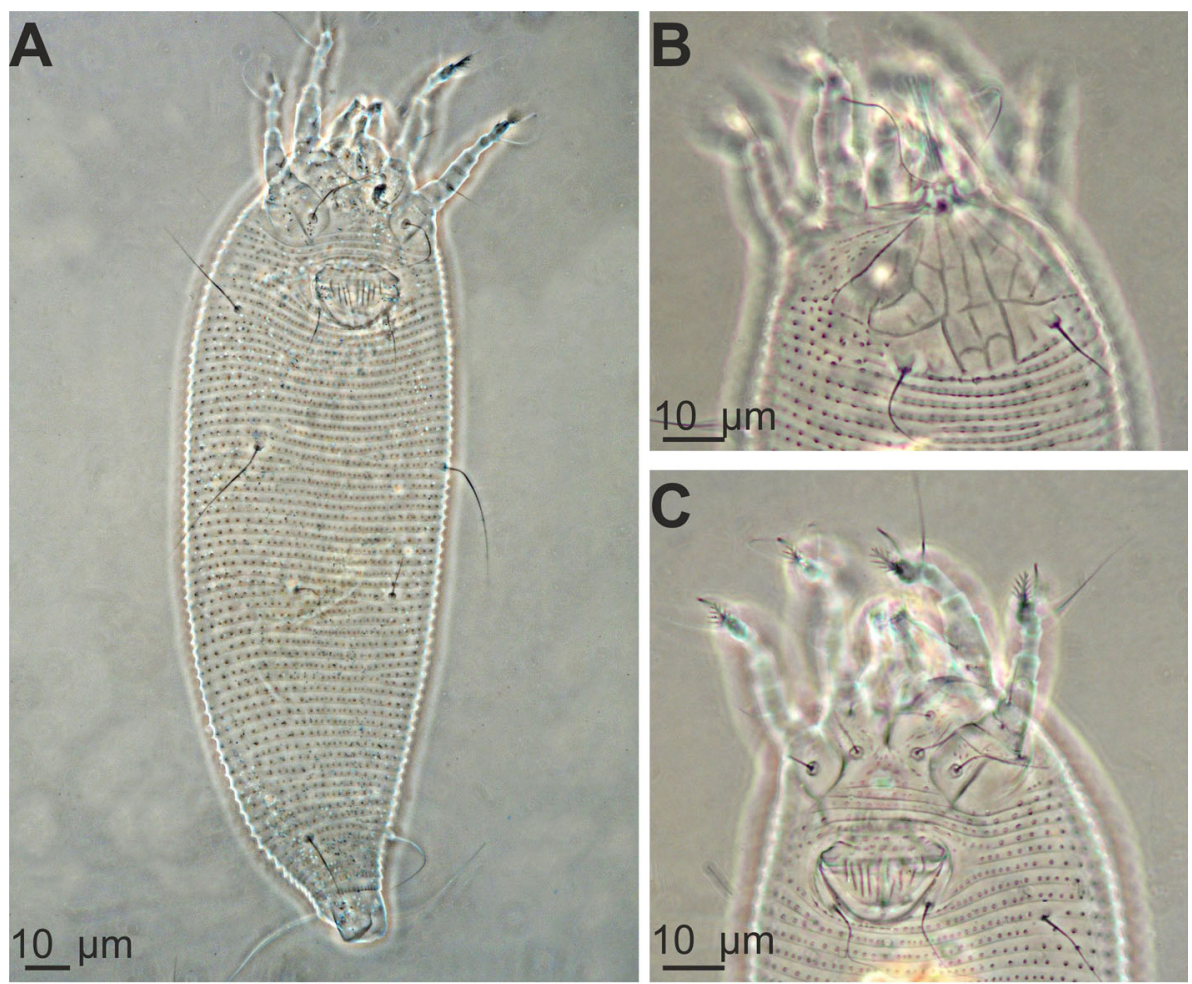

between tubercles $1 a$ and $2 a$ 8. External genitalia 17-18, 22-24 wide, genital coverflap with 9-11 longitudinal ridges; setae $3 a 15-16$, tubercles $3 a$ 18-20 apart. Opisthosoma vermiform; 62-63 dorsal annuli, 61-65 ventral annuli. Microtubercles near rear margin of the annuli; rounded. Opisthosomal setae: $c 2$ 25-33, tubercles 55-69 apart, on 8-9 ventral annulus; $d$ 35-41, tubercles 46-54 apart, on 20-24 ventral annulus; $e$ 12-13, tubercles 23-28 apart, on 33-37 ventral annulus; $f 20-25$, tubercles $22-27$ apart, on 54-59 ventral annulus, 5-6 annulus from rear. Setae $h l$ 4-5, 7-8 apart; setae $h 2$ 40-58, 10-11 apart; distance between $h 1$ and $h 2$ 2-3.

Material: Six females from northern coast of Hornsund, Wedel Jarlsberg Land, $77^{\circ} 00^{\prime} \mathrm{N}, 15^{\circ} 19.8^{\prime}$, August 2011 from S. oppositifolia (Saxifragaceae), leg. K. Zawierucha. Material is deposited in the collection of the Faculty of Biology, Adam Mickiewicz University, Poznań, Poland.

Relation to the host: Free-living on leaves. According to previous observations (Rostrup 1900; Liro 1940; James Amrine personal communication), A. saxifragae has been found both free-living and inhabiting buds. In the course of our study, we did not found any mite specimens inside buds. All recorded specimens observed in dried samples were associated with plant leaves.

Remarks: Female A. saxifragae specimens collected in South Spitsbergen National Park in this study differed morphologically both from the specimens presented in the original description (Rostrup 1900) and a subsequent description by Liro (1940) due to their shorter sc setae [as can be observed in the line drawings provided by Liro (1940)] and 5-rayed empodium (it is four-rayed in the earlier descriptions). Moreover, the prodorsal shield pattern (not described, but only presented in figures by previous authors) is more striking and complicated compared to earlier descriptions. The prodorsal shield pattern of specimens in this study is composed of an incomplete median line, which appears as a long line in the front $3 / 4$ with a transverse line in the rear $1 / 3$ and two short arcs at the rear shield margin; admedian lines are complete, and the submedian lines form a mosaic pattern. The prodorsal shield pattern presented by Liro (1940) lacks the transverse line and mosaic pattern. Despite considerable effort made to find type material of A. saxifragae (James W. Amrine, West Virginia University and Nikolaj Scharff, Natural History Museum of Denmark, personal communication), we were not able to confirm neither the type collection still exists nor where it was deposited. Therefore, we were only able to compare our complementary description to the descriptions by Rostrup (1900) and Liro (1940). Unfortunately, such situations are common for type materials of many eriophyoid species (James W. Amrine personal communication). Nevertheless, the differences observed between the original descriptions and material examined by us may be the result of (1) human perception bias, (2) limitations in the state of the art, and/or (3) phenotypic 


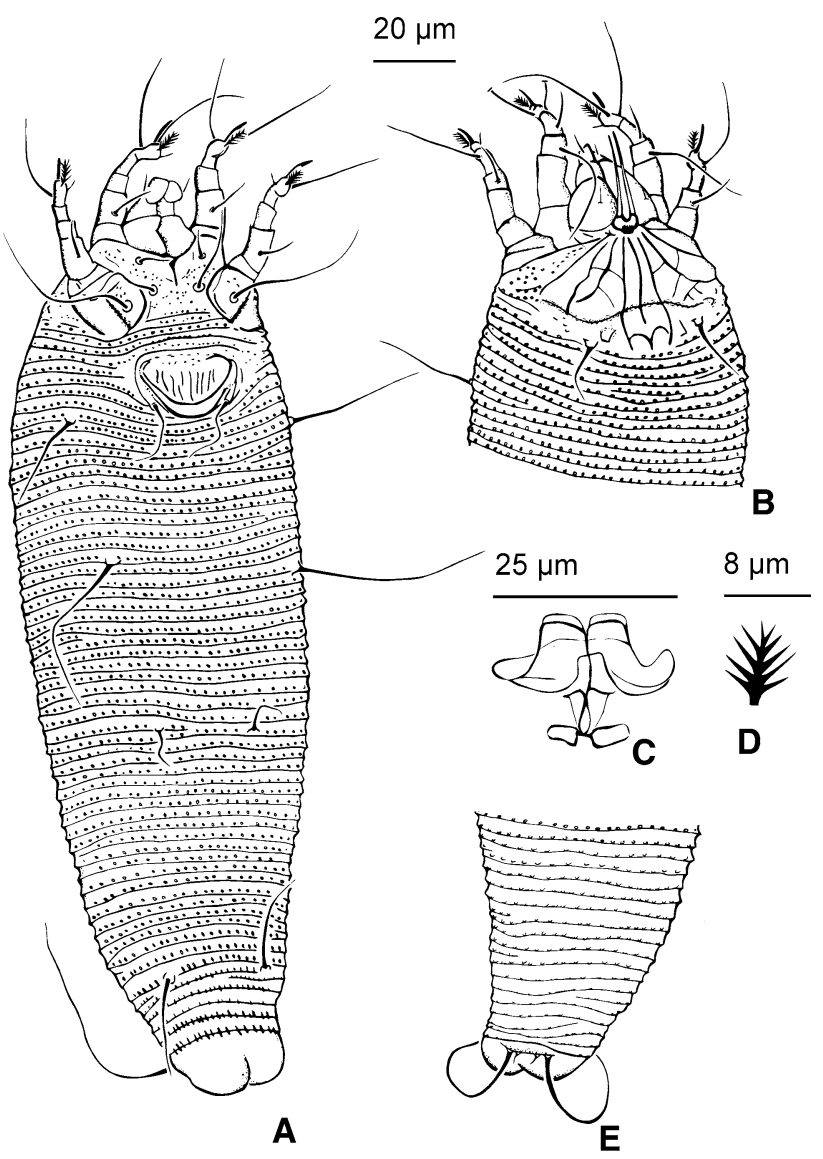

Fig. 5 Aceria saxifragae female: a ventral mite; $\mathbf{b}$ anterodorsal mite; c internal genitalia; d empodium; e posterodorsal mite; scale bar $\mathbf{a}, \mathbf{b}$, $\mathbf{e}-20 \mu \mathrm{m} ; \mathbf{c}-25 \mu \mathrm{m} ; \mathbf{d}-8 \mu \mathrm{m}$

variation among populations of A. saxifragae. A century ago, microscopy was not as precise or discriminating as today, thus the descriptions of eriophyoid species of that time lacked detail and accuracy, the result being sub-optimal measurements and drawings. Thus, it is possible that some lines on the prodorsal shield of A. saxifragae may have been missed in the initial descriptions. Quantitative morphological traits can also vary in eriophyoid mites, and this variation may exist between populations separated geographically or by host association (e.g., Navia et al. 2009; Shen et al. 2014). Thus, the observed differences in the length of $s c$ setae and the number of empodial rays may reflect intraspecies variation.

\section{Discussion}

There is undoubtedly a general lack of knowledge of eriophyoid mite distributions in Arctic regions. A small number of eriophyoid mite species have been reported from Greenland, Iceland, and Arctic Russia, e.g., A. saxifragae (Rostrup, 1900); A. reykjaviki Szydło, Skaftason and Skoracka,
2010; A. thomasi (Nalepa, 1889); Aculops pedicularis (Nalepa, 1892); A. thymi (Nalepa, 1889); Aculus groenlandicus (Rostrup, 1900); A. tetanothrix (Nalepa, 1889); Phyllocoptes empetri Rostrup, 1900 (Amrine 2003; Szydło et al. 2010), as well as one possibly accidental specimen from Svalbard belonging to the genus Eriophyes (Thor 1934). The study described here represents an important contribution to taxonomic research on Eriophyoidea on Svalbard, and reports one new species of eriophyoid mite with bar-code data and one new record of A. saxifragae with a supplementary morphological description.

Aceria saxifragae was originally described from $S$. oppositifolia in Greenland (Rostrup 1900). It has subsequently been recorded on the same host plant in Finland, Sweden, and mainland of Norway (Amrine 2003), although these faunistic records imply neither a definitive place of origin of this mite species nor any conclusions about the possible changing distribution of A. saxifragae. Saxifraga oppositifolia is not listed as a native of Svalbard (Jónsdóttir 2005). However, it is listed as native to nearby Greenland, as well as Canada, Alaska, and the northern continental USA (USDA-NRCS 2015). Given that most eriophyoid species are host specialists (Skoracka et al. 2010), it is likely that both eriophyoid species found on $S$. oppositifolia in this study, A. saxifragae and C. siedleckii n. sp., arrived to Svalbard with their host plant. To better understand where these mite species originated and how they are distributed, more comprehensive studies comparing mite populations and their host plants from different localities (e.g., Greenland, Canada, Alaska, mainland Scandinavia), as well as surveys of mites on close relatives of $S$. oppositifolia that are present on Svalbard, would be useful, preferably including DNA marker data that can discriminate between intraspecific populations. Moreover, to explain possible routes of mite dispersal and how they arrived on Svalbard, it would be useful in particular to collect populations found near transport hubs to/from Svalbard, such as in mainland Norway.

Overall, there has been a lack of comprehensive sampling effort for phytophagous mites in the Arctic. Of those locations that have been surveyed, many were only sampled on one occasion, often by non-specialists (Coulson et al. 2014a), resulting in sub-optimal sampling methods that yield incomplete data. The paucity of knowledge regarding eriophyoid mites inhabiting the Arctic likely results in part from methodological difficulties. Eriophyoid mites are minute organisms, and their detection and identification require specialized training.

Effects of changing climates will vary from region to region (Hodkinson 2013). Climate warming in the Arctic is expected to modify regional plant communities. For example, warmer and longer growing seasons are leading to an overall increase in the abundance of deciduous woody 
shrub species such as dwarf birch (Betula nana L. 1753) and willows (Salix spp. L.) (Sturm et al. 2001; Tape et al. 2006; Forbes et al. 2010). The number of invasive species is also increasing globally, in part as a result of intensified and accelerated human trade and travel (e.g., Kobelt and Nentwig 2008; Coulson 2013). This is especially true for plants in Svalbard (Alsos et al. 2007). The frequency and abundance of phytophagous arthropods associated with these plants, both native and introduced, are also likely to increase as a result of these changes. Eriophyoid mites can be very damaging to their host plants (Lindquist and Amrine 1996). Although most eriophyoids are highly hostspecific, numerous eriophyoid species are generalist pests of a variety of crop species (e.g., Aceria tulipae, Aceria tosichella, Abacarus hystrix; Skoracka et al. 2010). This, combined with the known ability of many eriophyoids to vector plant diseases (Oldfield and Proeseler 1996), underlines the urgent need to fill gaps in knowledge of phytophagous mite ecology and taxonomy in high Arctic habitats. This is particularly true of the Svalbard archipelago, whose location near the confluence of ocean currents and air masses of varied thermal characteristics (Humlum et al. 2007) makes it one of the most climatically sensitive regions in the world (Rogers et al. 2005).

Acknowledgments The study was financially supported by Faculty of Biology, Adam Mickiewicz University (AMU), Poznań, Poland, and partially by the Polish Ministry of Science and Higher Education via the "Diamond Grant" programme (Grant No. DIA 2011035241 to K.Z.). The authors are grateful to Prof. James Jr. Amrine for helpful information regarding eriophyoid mites occurring in Arctic, Dr. Nikolaj Scharff for information about type material of Aceria saxifragae, Dr. Ziemowit Olszanowski (AMU) for the assistance regarding taxonomical nomenclature, and Prof. Karol Latowski (AMU) for the confirmation of the botanical taxonomic identification.

\section{Compliance with ethical standards}

Conflict of interest The authors declare that they have no conflict of interest.

Open Access This article is distributed under the terms of the Creative Commons Attribution 4.0 International License (http://crea tivecommons.org/licenses/by/4.0/), which permits unrestricted use, distribution, and reproduction in any medium, provided you give appropriate credit to the original author(s) and the source, provide a link to the Creative Commons license, and indicate if changes were made.

\section{References}

Alsos IG, Eidesen PB, Ehrich D, Skrede I, Westergaard K, Jacobsen GH, Landvik JY, Taberlet P, Brochmann C (2007) Frequent long-distance plant colonization in the changing arctic. Science 316:1601-1608

Amrine JW Jr (2003) Catalog of the Eriophyoidea. A working catalog of the Eriophyoidea of the world. Ver. 1.0. http://insects.tamu. edu/research/collection/hallan/acari/eriophyidae. Accessed 1 Apr 2015

Amrine JW Jr, Stasny TAH, Flechtmann CHW (2003) Revised keys to the world genera of the Eriophyoidea (Acari: Prostigmata). Indira Publishing House, West Bloomfield

Baker EW, Kono T, Amrine JW Jr, Delfinado-Baker M, Stasny TA (1996) Eriophyoid mites of the United States. Indira Publishing House, West Bloomfield

Coulson SJ (2013) The terrestrial invertebrate fauna of the Svalbard Archipelago in a changing world; history of research and challenges. Can Entomol 145:131-146

Coulson SJ, Refseth D (2004) Chapter 3. The terrestrial and freshwater invertebrate fauna of Svalbard (and Jan Mayen). In: Prestrud P, Strøm H, Goldman HV (eds) A catalogue of the terrestrial and marine animals of Svalbard. Troms $\varnothing$, Norwegian Polar Institute, pp 57-122

Coulson SJ, Hodkinson ID, Webb NR (2003) Aerial dispersal of invertebrates over a high-Arctic glacier foreland: Midtre Lovénbreen, Svalbard. Polar Biol 26:530-537

Coulson SJ, Schatz H, Gwiazdowicz DJ, Solhøy T (2014a) On the oribatid and mesostigmatid mites (Acari) of the high arctic Island of Hopen. Pol Polar Res 35:133-139

Coulson SJ, Convey P, Aakra K, Aarvik L, Ávila-Jiménez ML, Babenko A, Biersma EM, Boström S, Brittain JE, Carlsson AM, Christoffersen K, De Smet WH, Ekremj T, Fjellberg A, Füreder L, Gustafssonm D, Gwiazdowicz DJ, Hansen LO, Holmstrup M, Hullé M, Kaczmarek Ł, Kolicka M, Kuklin V, Lakka HK, Lebedeva N, Makarova O, Maraldo K, Melekhina E, Ødegaard F, Pilskog HE, Simon JC, Sohlenius B, Solhøy T, Søli G, Stur E, Tanasevitch A, Taskaeva A, Velle G, Zawierucha K, Zmudczyńska-Skarbek K (2014b) The terrestrial and freshwater invertebrate biodiversity of the archipelagoes of the Barents Sea; Svalbard, Franz Josef Land and Novaya Zemlya. Soil Biol Biochem 68:440-470

Coulson SJ, Fjellberg A, Melekhina EN, Taskaeva AA, Lebedeva NV, Belkina O, Seniczak S, Seniczak A, Gwiazdowicz DJ (2015) Microarthropod communities of disturbed or imported soils in the High Arctic; the abandoned coal mining town of Pyramiden. Biodivers Conserv, Svalbard. doi:10.1007/s10531015-0885-9

Dabert J, Ehrnsberger R, Dabert M (2008) Glaucalges tytonis sp. n. (Analgoidea, Xolalgidae) from the barn owl Tyto alba (Strigiformes, Tytonidae): compiling morphology with DNA barcode data for taxon descriptions in mites (Acari). Zootaxa 1719:41-52

Dabert M, Coulson SJ, Gwiazdowicz DJ, Moe B, Hanssen SA, Biersma EM, Pilskog HE, Dabert J (2014) Differences in speciation progress in feather mites (Analgoidea) inhabiting the same host: the case of Zachvatkinia and Alloptes living on arctic and longtailed skuas. Exp Appl Acarol 65:163-179

Dastych H (1985) West Spitsbergen Tardigrada. Acta Zool Crac 28:169-214

Dastych H, Drummond AE (1996) Notes on limnic water-bears (Tardigrada) from the Robertskollen nunataks, Dronning Maud Land, Antartica. Entomol Mitt Zool Mus Hamburg 12:111-117

de Lillo E, Craemer C, Amrine JW, Nuzzaci G (2010) Recommended procedures and techniques for morphological studies of Eriophyoidea (Acari: Prostigmata). Exp Appl Acarol 51:283-307

Duso C, Castagnoli M, Simoni S, Angeli G (2010) The impact of eriophyoids on crops: recent issues on Aculus schlechtendali, Calepitrimerus vitis and Aculops lycopersici. Exp Appl Acarol 51:151-168

Forbes BC, Fauria MM, Zetterberg P (2010) Russian Arctic warming and "greening" are closely tracked by tundra shrub willows. Glob Change Biol 16:1542-1554

Górska B, Grzelak K, Kotwicki L, Hasemann Ch, Scheweb I, Soltwedel T, Włodarska-Kowalczuk M (2014) Bathymetric 
variations in vertical distribution patterns of meiofauna in the surface sediments of the deep Arctic ocean (HAUSGARTEN, Fram strait). Deep-Sea Res I 91:36-49

Gwiazdowicz DJ, Coulson SJ, Grytnes JA, Pilskog HE (2012) The bird ectoparasite Dermanyssus hirundinis (Acari, Mesostigmata) in the High Arctic: a new parasitic mite to Spitsbergen, Svalbard. Acta Parasitol 57:378-384

Hackman W, Nyholm ES (1968) Notes on the arthropod fauna of Spitsbergen II. 9. Mallophaga from Spitsbergen and Bear Island. Ann Entomol Fenn 34:75-82

Hall TA (1999) BioEdit: a user-friendly biological sequence alignment editor and analysis program for Windows 95/98/NT. Nucleic Acids Symp Ser 41:95-98

Halvorsen O, Bye K (1999) Parasites, biodiversity, and population dynamics in an ecosystem in the High Arctic. Vet Parasitol 84:205-227

Hodkinson ID (2013) Terrestrial and freshwater invertebrates. In: Meltofte $\mathrm{H}$ (ed) Arctic biodiversity assessment. Status and Trends in Arctic biodiversity. Conservation of Arctic Flora and Fauna, Akureyri, pp 194-223

Humlum O, Christiansen HH, Juliussen H (2007) Avalanche-derived rock glaciers in Svalbard. Permafrost Periglac 18:75-88

Janiec K (1996) The comparison of freshwater invertebrates of Spitsbergen (Arctic) and King George Island (Antarctic). Pol Polar Res 17:173-202

Johnsen G, Candeloro M, Berge J, Moline M (2014) Glowing in the dark: discriminating patterns of bioluminescence from different taxa during the Arctic polar night. Polar Biol 37:707-713

Jónsdóttir IS (2005) Terrestrial ecosystems on Svalbard: heterogeneity, complexity and fragility from an Arctic Island perspective. Biol Environ 105:155-165. doi:10.3318/BIOE. 2005.105.3.155

Kaczmarek Ł, Zawierucha K, Smykla J, Michalczyk Ł (2012) Tardigrada of the Revdalen (Spitsbergen) with the descriptions of two new species: Bryodelphax parvuspolaris (Heterotardigrada) and Isohypsibius coulsoni (Eutardigrada). Polar Biol 35:1013-1026

Kobelt M, Nentwig W (2008) Alien spider introductions to Europe supported by global trade. Divers Distrib 14:273-280

Kuklin VV, Galkin AK, Marasaev SF, Marasaeva EF (2004) The characteristics of the helminthofauna of sea birds of the Svalbard Archipelago. Dokl Biol Sci 395:124-126

Lewandowski M, Skoracka A, Szydło W, Kozak M, Druciarek T, Griffiths D (2014) Genetic and morphological diversity of Trisetacus species (Eriophyoidea: Phytoptidae) associated with coniferous trees in Poland: phylogeny, barcoding, host and habitat specialization. Exp Appl Acarol 63:497-520

Lindquist EE (1996) External anatomy and notation of structures. In: Lindquist EE, Sabelis MW, Bruin J (eds) Eriophyoid mites: their biology, natural enemies and control. Elsevier, Amsterdam, pp 3-31

Lindquist EE, Amrine JW (1996) Systematics, diagnoses for major taxa, and keys to families and genera with species on plants of economic importance. In: Lindquist EE, Sabelis MW, Bruin J (eds) Eriophyoid mites: their biology, natural enemies and control. Elsevier, Amsterdam, pp 33-87

Lippert H, Iken K, Rachor E, Wiencke C (2001) Macrofauna associated with macroalgae in the Kongsfjord (Spitsbergen). Polar Biol 24:512-522

Liro JI (1940) Neue Eriophyiden aus Finland. Ann Zool Soc Zool-Bot Fenn Vanamo 8:1-67

MacFadyen A (1954) The invertebrate fauna of Jan Mayen Island (East Greenland). J Anim Ecol 23:261-297

Michalska K, Skoracka A, Navia D, Amrine JW (2010) Behavioural studies on eriophyoid mites: an overview. Exp Appl Acarol $51: 31-59$
Miller AD, Skoracka A, Navia D, de Mendonca RS, Szydło W, Schultz MB, Smith CM, Truol G, Hoffmann A (2013) Phylogenetic analyses reveal extensive cryptic speciation and host specialization in an economically important mite taxon. Mol Phylogenet Evol 66:928-940

Mironov SV, Dabert J, Dabert M (2012) A new feather mite species of the genus Proctophyllodes Robin, 1877 (Astigmata: Proctophyllodidae) from the Long-tailed Tit Aegithalos caudatus (Passeriformes: Aegithalidae)—morphological description with DNA barcode data. Zootaxa 3253:54-61

Navia D, Moraes G, Querino R (2009) Geographic pattern of morphological variation of the coconut mite, Aceria guerreronis Keifer (Acari: Eriophyidae), using multivariate morphometry. Braz J Biol 69:773-783

Navia D, Ochoa R, Welbourn C, Ferragut F (2010) Adventive eriophyoid mites: a global review of their impact, pathways, prevention and challenges. Exp Appl Acarol 51:225-255

Oldfield GN, Proeseler G (1996) Eriophyoid mites as vectors of plant pathogens. In: Lindquist EE, Sabelis MW, Bruin J (eds) Eriophyoid mites: their biology, natural enemies and control. Elsevier Science BV, Amsterdam, pp 259-273

Pilskog HE, Solhøy T, Gwiazdowicz DJ, Grytnes JA, Coulson SJ (2014) Invertebrate communities inhabiting nests of migrating passerine, wild fowl and sea birds breeding in the High Arctic, Svalbard. Polar Biol 37:981-998

Porazińska DL, Fountain AG, Nylen TH, Tranter M, Virginia RA, Wall DH (2004) The biodiversity and biogeochemistry of cryoconite holes from McMurdo Dry Valley glaciers, Antarctica. Arct Antarct Alp Res 36:84-91

Rogers JC, Yang L, Li L (2005) The role of Fram Strait winter cyclones on sea ice flux and on Spitsbergen air temperatures. Geophys Res Lett. doi:10.1029/2004GL022262

Rostrup S (1900) Gronlandske Phytoptider. Vidensk Medd naturhist Foren Kobenharn 6:241-249

Shen TJ, Kuo CC, Wang CF, Huang KW (2014) Delimitation of a continuous morphological character with unknown prior membership: application of a finite mixture model to classify scapular setae of Abacarus panticis. Exp Appl Acarol 63:361-375

Skoracka A, Smith L, Oldfield GN, Cristofaro M, Amrine JW (2010) Host- plant specificity and specialization in eriophyoid mites and their importance for the use of eriophyoid mites on biocontrol agents of weeds. Exp Appl Acarol 51:93-113

Skoracka A, Kuczyński L, de Mendonca R, Dabert M, Szydło W, Knihinicki D, Truol G, Navia D (2012) Cryptic species within the wheat curl mite Aceria tosichella (Keifer) (Acari, Eriophyoidea) revealed by mitochondrial, nuclear and morphometric data. Invertebr Syst 26:417-433

Skoracka A, Kuczyński L, Szydło W, Rector B (2013) The wheat curl mite Aceria tosichella (Acari: Eriophyoidea) is a complex of cryptic lineages with divergent host ranges: evidence from molecular and plant bioassay data. Biol J Linn Soc 109:165-180

Skoracka A, Kuczyński L, Rector B, Amrine JW Jr (2014) Wheat curl mite and dry bulb mite: untangling a taxonomic conundrum through a multidisciplinary approach. Biol J Linn Soc 111:421-436

Sonnenberg R, Nolte AW, Tautz D (2007) An evaluation of LSU rDNA D1-D2 sequences for their use in species identification. Front Zool. doi:10.1186/1742-9994-4-6

Stien A, Voutilainen L, Haukisalmi V, Fuglei E, Mork T, Yoccoz NG, Ims RA, Henttonen H (2010) Intestinal parasites of the arctic fox in relation to the abundance and distribution of intermediate hosts. Parasitology 137:149-157

Sturm M, Racine C, Tape K (2001) Climate change: increasing shrub abundance in the Arctic. Nature 411:546-547

Summerhayes VS, Elton CS (1928) Further contributions to the ecology of Spitsbergen. J Ecol 16:193-268 
Szydło W, Skaftason JF, Skoracka A (2010) Eriophyoid mites (Prostigmata: Eriophyoidea: Eriophyidae) from Iceland: one new species, and three new mite records. Ann Zool 60:139-157

Szydło W, Hein G, Denizhan E, Skoracka A (2015) Exceptionally high levels of genetic diversity in wheat curl mite (Acari: Eriophyidae) populations from Turkey. J Econ Entomol 108:2030-2039

Tamura K, Stecher G, Peterson D, Filipski A, Kumar S (2013) MEGA6: molecular evolutionary genetics analysis version 6.0. Mol Biol Evol 30:2725-2729

Tape K, Sturm M, Racine C (2006) The evidence for shrub expansion in northern Alaska and the pan-Arctic. Glob Change Biol 12:686-702

Thor S (1930) Beitrage zur Kenntnis der invertebraten Fauna von Svalbard. Skrifter om Svalbard og Ishavet 27. Norwegian Polar Institute, Oslo

Thor S (1934) Neue Beitrage zur Kenntnis der invertebraten Fauna von Svalbard. Zool Anz 107:114-139

USDA, NRCS (2015) The PLANTS database (http://plants.usda.gov, 27 April 2015). National Plant Data Team, Greensboro, NC 27401-4901 USA

Walkera MD, Wahrenb CH, Hollisterc RD, Henryde GHR, Ahlquistf LE, Alatalog JM, Bret-Harteh MS, Calefh MP, Callaghani TV,
Carrolla AB, Epsteinj HE, Jónsdóttirk IS, Kleinl JA, Magnússonm B, Molaug U, Oberbauerf SF, Rewan SP, Robinsono CH, Shaverp GR, Sudingq KN, Thompsonr CC, Tolvanens A, Totlandt $\varnothing$, Turneru PL, Tweediev CE, Webberw PJ, Wookeyx PE (2006) Plant community responses to experimental warming across the tundra biome. PNAS 103:1342-1346

Walter DE, Proctor HC (2013) Mites: ecology, evolution \& behaviour: life at a microscale, 2nd edn. Springer, Netherlands, pp $1-494$

Xue XF, Song ZW, Hong XY (2011) Three new species of Cecidophyinae (Acari: Eriophyidae) from China. J Nat Hist 45:1200-1203

Zawierucha K (2013) Tardigrada from Arctic tundra (Svalbard, Spitsbergen) with a description of Isohypsibius karenae (Eutardigrada: Isohypsibiidae). Pol Polar Res 34:383-396

Zawierucha K, Coulson S, Michalczyk Ł, Kaczmarek Ł (2013) Current knowledge of the Tardigrada of Svalbard with the first records of water bears from Nordaustlandet (High Arctic). Polar Res 32:20886. doi:10.3402/polar.v32i0.20886

Zawierucha K, Smykla J, Michalczyk Ł, Gołdyn B, Kaczmarek Ł (2015) Distribution and diversity of Tardigrada along altitudinal gradients in the Hornsund, Spitsbergen (Arctic). Polar Res 34:24168. doi:10.3402/polar.v34.24168 